\title{
IMPLEMENTASI PEMBELAJARAN KIMIA POKOK BAHASAN MINYAK BUMI BERORIENTASI PEMBELAJARAN TERPADU TIPE IMMERSED
}

\author{
Lutfiana Fazat Azizah \\ Prodi Pendidikan IPA, Universitas Wiraraja Sumenep
}

\begin{abstract}
ABSTRAK
Telah dilakukan penelitian mengembangkan perangkat pembelajaran RP, LKS, Buku Siswa dan Tes Hasil Belajar yang berorientasi model Kemp dengan pembelajaran terpadu tipe immersed antara minyak bumi, viskositas dan dampak terhadap lingkungan. Subyek penelitian 30 siswa MAN Surabaya kelas X-1, X-2, X-3 dan X-4 tahun pembelajaran 2006/2007 dengan pretest- posttest control group design. Analisis data ternyata frekuensi aktivitas siswa untuk kelas eksperimen selama kegiatan cukup baik pada aspek afektif, kognitif dan psikomotor rata-rata mengalami peningkatan $10 \%$, respon siswa baik, dan sebagian besar siswa menyatakan jelas terhadap bimbingan guru, senang terhadap latihan dan pemecahan masalah, sangat berminat untuk mengikuti kegiatan pembelajaran berikutnya. Hasil belajar siswa kelas eksperimen $75 \%$ dan $80 \%$, kelas kontrol 60\%. Dapat disimpulkan bahwa pembelajaran terpadu tipe immersed ternyata mean score beda lebih baik tapi tidak signifikan.
\end{abstract}

Kata Kunci: pembelajaran terpadu tipe immersed, model kemp, materi minyak bumi

\section{PENDAHULUAN}

Pendidikan mempunyai peranan penting dalam memajukan bangsa dan negara. Dalam era globalisasi dimana ilmu pengetahuan dan teknologi berkembang dengan pesat, diharapkan perkembangan ilmu pengetahuan dan teknologi berjalan seiring dengan perkembangan kualitas pendidikan dan sistem pengajaran di Indonesia. Kenyataan menunjukkan bahwa perkembangan dan kemajuan di segala bidang ditentukan oleh keberhasilan pendidikan sehingga mutu pendidikan harus senantiasa ditingkatkan. Pendidikan hendaknya berorientasi jauh ke depan dan berfikir pada masalah-masalah yang dihadapi oleh peserta didik pada masa yang akan datang, sehingga pemerintah Indonesia dalam hal ini Departemen Pendidikan dan Kebudayaan selalu berupaya atau berusaha untuk meningkatkan sistem pendidikan yang ada di Indonesia. Berbagai cara ditempuh untuk meningkatkan mutu pendidikan antara lain pengembangan dan penyempurnaan kurikulum, pengembangan kualitas proses belajar mengajar (Pengembangan perangkat pembelajaran) dan meningkatkan mutu tenaga pengajar.

Perhatian pemerintah yang besar terhadap bidang pendidikan ditunjukkan dengan disusunnya kurikulum 2004 yang menuntut siswa untuk aktif dalam kegiatan belajar mengajar. Untuk mencapai tujuan tersebut diperlukan suatu pembelajaran yang berpusat pada siswa (Student Centered). Salah satu pembelajaran yang berpusat pada siswa adalah pembelajaran terpadu (Fogarty : 1991).

Pengembangan ketrampilan proses dan sikap ilmiah mengisyaratkan bahwa tidaklah cukup bagi siswa hanya menguasai konsep- konsep kimia sebagai suatu informasi yang tersimpan dalam benaknya tetapi mampu menggunakan konsepkonsep tersebut untuk memecahkan masalah yang dihadapi sehari- hari. Sebab banyak masalah dalam kehidupan muncul bukan karena siswa tidak memiliki pengetahuan, tetapi ketidakmampuannya untuk menggunakan pengetahuan yang dimilikinya.

William James, dalam buku yang berjudul Talks to Teachers on Psychology (1972) seperti yang dikutip oleh Nur (1998: 27) mengatakan guru dapat membantu siswa belajar informasi sedemikian rupa sehingga menjadikan informasi itu disamping berguna juga bermakna bagi mereka. Pengajaran yang efektif memerlukan suatu pemahaman tentang bagaimana menjadikan informasi dapat diakses oleh siswa sehingga mereka dapat 
menghubungkan informasi itu dengan informasi lain dan menerapkan informasi itu di luar kelas.

Mencapai tujuan ini, guru secara khusus memiliki peran sangat penting dalam mengemas pembelajaran yang dapat memberikan siswa kesempatan untuk mengembangkan berbagai kompetensi sesuai dengan potensinya masing- masing. Dalam hal ini siswa merupakan subyek belajar, dan proses belajar berlangsung secara alamiah dalam bentuk bekerja dan mengalami berdasarkan standar kompetensi tertentu, bukan transfer pengetahuan (Mulyasa, 2002: 69).

Demikian pula, dalam kegiatan pembelajaran guru tidak secara sengaja merancang perangkat pembelajaran yang melatih siswa sejumlah ketrampilan yang diperlukannya untuk mengembangkan kompetensinya. Guru hanya berharap ketercapaian kompetensi siswa akan terbentuk secara otomatis seiring dengan terkuasainya substansi mata pelajaran. Sehingga masyarakat/ orang tuapun kadangkadang mencemoohkan dan menuding guru tidak kompeten, tidak berkualitas dan sebagainya, manakala putra/ putrinya tidak bisa menyelesaikan persoalan yang ia hadapi (Trianto), 2005).

Terjadinya pengkotak- kotakan atau pemilihan suatu konsep yang terkait dari mata pelajaran lain menyebabkan pemahaman siswa yang terbentuk hanya sebatas pandangan masing- masing mata pelajaran menyebabkan tiadanya keterkaitan antar konsep. Dengan kata lain bahwa seolah- olah antar konsep berdiri sendiri. Hal ini akan memudarkan keterpaduannya serta para siswa tidak dapat memahami kajian konsep sebagai suatu sistem yang utuh (Prabowo, 2000). Akibat lain adalah tidak optimalnya materi pelajaran yang diserap siswa karena media laboratorium tidak diberdayakan secara optimal dalam menunjukkan gagasan, prinsip, hukum dan teori dari materi pembelajaran yang sedang dikaji sebagai pendukung daya ingat siswa (Nur, 2000).

Hasil penelitian Balitbang Dikdasmen Dikti, juga menunjukkan bahwa dalam proses pembelajaran guru cenderung memilih pendekatan dan strategi pembelajaran yang hanya memacu siswa untuk mengingat dan menghafal konsepkonsep yang ada. Proses pembelajaran hanya menggunakan metode ceramah dengan cara komunikasi satu arah, dengan $90 \%$ keaktifan terletak pada pengajar, sedangkan siswa hanya semata- mata memfungsikan indera penglihatan dan indera pendengaran saja (Trianto, 2005). Hasil penelitian Trianto (2005), menunjukkan bahwa implementasi pembelajaran terpadu tipe integrated pada mata pelajaran fisika ternyata mean score lebih baik.

Rata- rata nilai rapor kelas I MAN Surabaya dapat dilihat pada tabel 1, menunjukkan bahwa mutu hasil belajar kimia kurang.

Tabel 1. Rekapitulasi Rata-Rata Nilai Rapor Kelas X di MAN Surabaya

\begin{tabular}{|c|c|c|c|c|}
\hline No. & $\begin{array}{c}\text { Tahun } \\
\text { Pelajaran }\end{array}$ & Nilai Fisika & Nilai Kimia & $\begin{array}{c}\text { Nilai } \\
\text { Geografi }\end{array}$ \\
\hline 1. & $2002 / 2003$ & 5,6 & 5,9 & 6,3 \\
\hline 2. & $2003 / 2004$ & 5,1 & 5,8 & 5,9 \\
\hline 3. & $2004 / 2005$ & 5,2 & 5.7 & 5,8 \\
\hline
\end{tabular}

(Sumber:MAN Surabaya)

Berdasarkan latar belakang permasalahan yang dikemukakan di atas, peneliti tertarik mengembangkan perangkat pembelajaran yang dapat melatih siswa sejumlah ketrampilan yang diperlukan untuk mengembangkan kompetensinya. Peneliti menduga salah satu alternatif pembelajaran yang sesuai untuk maksud tersebut adalah pembelajaran terpadu tipe immersed (pembenaman) yaitu suatu 
pembelajaran yang menggunakan pendekatan antar disiplin ilmu, dimana siswa dapat memadukan semua data dari setiap bidang ilmu dan menghasilkan pemikiran sesuai bidang minatnya untuk diterapkan dalam kehidupan sehari- hari (Fogarty, 1991). Fogarty (1991) mengemukakan bahwa ada sepuluh tipe pembelajaran terpadu, pada tipe immersed perpaduan dilakukan oleh siswa, guru hanya menyediakan fasilitas dan mengarahkan proses perpaduan yang dilakukan siswa, tipe immersed hanya sesuai untuk siswa dengan tingkat pemikiran yang sudah tinggi. Pada tipe integrated, perpaduan dilakukan sepenuhnya oleh guru, siswa hanya menerima materi terpadu, tipe ini dapat diterapkan pada semua tingkat pemikiran. Kekhasan tipe immersed mengharuskan peneliti untuk memilih subyek penelitian yang tepat. Sesuai dengan tahap- tahap perkembangan kognitif Piaget, pada tahap operasi formal, usia 11 tahun- dewasa, dimana pemikiran abstrak dan murni simbolis dapat dilakukan, masalah- masalah dapat dipecahkan melalui penggunaan eksperimentasi sistematis, maka peneliti menetapkan kelas $X$ tingkat SMA sebagai subyek penelitian yang tepat untuk pembelajaran terpadu tipe immersed.

Peneliti berharap melalui pembelajaran terpadu tipe immersed, siswa dapat memadukan materi kimia, fisika dan sosial dengan bidang interest tertentu. Konsep kimia yang dapat dikemas ke dalam model pembelajaran terpadu tipe immersed adalah konsep minyak bumi. Pengkajian konsep ini akan lebih bermakna bila dipadukan dengan materi ajar Fisika dan studi sosial. Studi sosial merupakan bahan ajar Ilmu sosial yang dapat dipadukan dengan konsep minyak bumi dalam kimia.

Langkah awal dari penyajian materi terpadu ini adalah melihat prioritas konsep penuntun dan terstruktur sebagai prasyarat tanpa mengutamakan salah satu mata pelajaran, hingga mampu mengikis adanya batas antara satu mata pelajaran dengan mata pelajaran lainnya. Cara pengemasan pembelajaran seperti ini diharapkan berdampak pada tumbuhnya kemampuan dasar siswa dalam melihat keterkaitan konsep satu terhadap konsep lainnya serta mampu mengaplikasikannya dalam kehidupan sehari- hari. Pemilihan konsep per mata pelajaran yang dikemas ke dalam model pembelajaran terpadu tipe immersed dan diterapkan pada konsep Minyak Bumi tersebut. Aplikasi konsep minyak bumi akan lebih bermakna apabila dikaitkan dengan kehidupan sehari- hari melalui studi sosial seperti dampak pembakaran bahan bakar terhadap lingkungan. Agar pemahaman konsep fluida menjadi lebih baik maka siswa harus diupayakan trampil menggunakan rumusrumus fisika tentang fluida.

Berdasarkan uraian latar belakang di atas, sebagai salah satu alternatif untuk meningkatkan kualitas pembelajaran, maka perlu dilakukan suatu penelitian yang berjudul: "Implementasi Pembelajaran Kimia Pokok Bahasan Minyak Bumi Berorientasi Pembelajaran Terpadu Tipe Immersed".

\section{METODE PENELITIAN}

Penelitian pada proses pembelajaran terpadu tipe immersed ini merupakan jenis penelitian tindakan kelas dengan menggunakan metode eksperimen. Dalam penelitian ini yang perlu dikembangkan adalah perangkat pembelajaran terlebih dahulu. Dalam penelitian ini yang dikembangkan antara lain: materi minyak bumi yang dipadukan dengan fluida dan studi sosial, perangkat pembelajaran yang berupa:Buku Siswa, LKS, RP.

Penelitian dilaksanakan pada siswa MA Negeri Surabaya kelas X-1, X-2, X-3 dan X-4, tahun ajaran 2006-2007. Waktu yang digunakan untuk pengambilan nilai uji awal, uji akhir dan pengisian angket respon, dilakukan di luar jam pelajaran.

Pengambilan data penelitian disesuaikan dengan jadwal proses belajar mengajar sekolah yang bersangkutan yaitu pada bulan Desember 2006 sampai Januari 2007. Adapun uji tes awal dan tes akhir menggunakan waktu diluar jam pelajaran. 
III. HASIL DAN PEMBAHASAN

\subsection{Pembahasan Hasil Pengembangan} Perangkat Pembelajaran

Pembahasan hasil dari penelitian pengembangan perangkat pembelajaran yang berorientasi pada pembelajaran terpadu tipe immersed ini didasarkan pada telaah oleh pakar-pakar yang sekaligus bertindak sebagai validator. Perangkat pembelajaran yang dikembangkan telah layak digunakan dengan revisi. Revisi dilakukan mengingat peneliti merupakan pemula dalam hal pengembangan perangkat pembelajaran sehingga masih cukup banyak terdapat kekurangan pada buku siswa, LKS, RP dan THB. Adapun perangkat pembelajaran yang dikembangkan pada penelitian ini telah dirancang sedemikian hingga mengikuti pola urutan pembelajaran terpadu tipe immersed.

\subsection{Pembahasan Hasil Aktivitas Siswa dalam KBM}

Pada uji coba 1 kelas kontrol, ratarata aktivitas siswa aspek kognitif yang menonjol adalah bertanya. Keterampilan berpendapat dan menanggapi pendapat baik uji coba 1 maupun uji coba 2 eksperimen 1 dan 2 sebagian besar masih kurang, yang dikarenakan siswa belum terbiasa berbicara di depan orang banyak atau tidak berani berbicara di depan umum. Aktivitas siswa aspek afektif yang menonjol adalah partisipasi dan kerjasama, hanya pada uji coba 1 untuk ketrampilan kerjasamanya kurang sekali, dikarenakan siswa belum beradaptasi dengan kelompoknya. Semua siswa baik pada uji coba 1 maupun uji coba 2 eksperimen 1 dan 2 aspek psikomotornya sebagian besar sudah baik, sehingga bisa dikatakan siswa tersebut kemampuan mengamati percobaan dan menyimpulkan hasil percobaan untuk kelas kontrol sudah baik. Dari hasil pengamatan aktivitas siswa kelas kontrol pada saat kegiatan belajar mengajar di atas terlihat bahwa aktivitas siswa paling baik terlihat pada aspek afektif dan psikomotor, sedangkan aspek kognitifnya kurang. Aspek kognitif kelas eksperimen pada keterampilan bertanya masih kurang. Hal ini dikarenakan siswa belum biasa berbicara didepan umum. Sehingga hasil dari pengamatan aktivitas siswa untuk kelas kontrol maupun kelas eksperimen dapat disimpulkan bahwa siswa kurang pada aspek kognitif karena dalam kurikulum 2004 siswa dituntut aktif dan mampu berkomunikasi dengan baik, mampu menyampaikan pendapat. Aspek psikomotor yang menonjol berturut- turut mengamati percobaan dan menyimpulkan hasil. Aktivitas siswa yang menonjol ini sesuai dengan karakteristik pembelajaran terpadu, yaitu memungkinkan siswa mengalami sendiri dalam kehidupan sehari- hari sesuai fakta yang ada, belajar jadi lebih bermakna, bersifat student centered (berpusat pada siswa). Arends (1997) menyatakan bahwa menyampaikan materi pelajaran dengan jelas dan spesifik kepada siswa mempunyai pengaruh positif terhadap aktivitas siswa. Persentase aktivitas rata- rata siswa yang meningkat pada kelas eksperimen menunjukkan bahwa materi, buku siswa, LKS dan cara guru menyampaikan materi dengan pembelajaran terpadu tipe immersed dapat menjadikan materi tersampaikan jelas dan spesifik pada siswa.

\subsection{Pembahasan Respon Siswa Terhadap Perangkat dan Proses Pembelajaran}

Data tabel 4.8; 4.9 dan 4.10 (dapat dilihat pada lampiran) menunjukkan ratarata respon siswa adalah positif. Siswa menyatakan senang belajar kimia dengan metode pembelajaran terpadu, karena jadi tahu penggunaan ilmu kimia dalam kehidupan sehari- hari, dapat memperluas wawasan, belajar kimia dengan metode pembelajaran terpadu penting untuk dilaksanakan pada materi- materi yang lain. Kondisi ini menunjukkan bahwa 
perangkat pembelajaran yang dikembangkan telah memenuhi syarat Atwater (1995) yang menyatakan bahwa perangkat pembelajaran yang dikembangkan harus menarik perhatian siswa. Perangkat pembelajaran ini meliputi buku siswa terpadu yang dilengkapi gambar- gambar terkini, LKS dengan aktivitas baru yang menarik siswa, tes hasil belajar yang memuat soal-soal kimia, fisika, dan studi sosial.

\subsection{Pembahasan Tes Hasil Belajar}

Rata-rata hasil nilai formatif setiap kegiatan RP tuntas secara individu pada kelas eksperimen maupun kontrol. Hasil nilai kognitif kelas eksperimen lebih tinggi dari kelas kontrol karena perlakuan yang dikenakan beda. Pada kelas eksperimen siswa melakukan percoban sendiri dengan bantuan LKS dan buku siswa, sedangkan kelas kontrol hanya dilakukan demonstrasi oleh guru dan salah satu siswa yang ditunjuk. Dari perbedaan perlakuan ini diperoleh hasil: siswa pada kelas eksperimen lebih paham materi karena dengan mereka melakukan percobaan sendiri, mereka menjadi lebih mengingat, lebih memiliki kesan dan lebih bersemangat untuk mempelajari materi minyak bumi. Kurikulum 2004 menyatakan tuntas klasikal apabila $75 \%$ dari jumlah siswa mencapai ketuntasan individu dengan daya serap $P \geq 0.75$. Uji coba 1 menunjukkan $85 \%$ siswa mencapai ketuntasan individu, artinya kurikulum 2004 menyatakan kelas eksperimen uji coba 1 tuntas klasikal. Uji coba 2 eksperimen 1 dan 2 menunjukkan berturut- turut $75 \%$ dan $80 \%$ siswa mencapai ketuntasan individu, artinya kurikulum 2004 menyatakan uji coba 2 kelas eksperimen tuntas klasikal. Nilai rata - rata menggambarkan adanya perbedaan hasil belajar antara kedua kelas dimana nilai rata - rata dari kelas eksperimen uji coba 1 dan uji coba 2 lebih tinggi daripada kelas kontrol dengan perbedaan berturut- turut sebesar 5,00; 5,00 dan 7,00. Menurut hasil analisis uji-t, untuk uji coba 1 nilai tes akhir kelas eksperimen 78 dan kelas kontrol 73, untuk uji coba 2 nilai tes akhir kelas eksperimen 1 dan 2 adalah 77 dan 79, kelas kontrol 72, sehingga dapat dikatakan hasil belajar siswa dengan pembelajaran terpadu tipe immersed ternyata mean score beda lebih baik tapi tidak signifikan. Data penelitian menunjukkan bahwa ketuntasan secara klasikal pada kelas eksperimen telah tercapai. Dengan melihat standar ketuntasan belajar pada Kurikulum 2004, maka hasil yang dicapai pada penelitian ini sudah terpenuhi. Sedangkan pada kelas kontrol masih belum terpenuhi. Hal ini disebabkan oleh banyak faktor diantaranya, siswa sudah terbiasa dengan pembelajaran yang diterapkan, sehingga banyak siswa yang bosan.

\section{KESIMPULAN DAN SARAN \\ 4.1 Kesimpulan}

Dapat disimpulkan implementasi pembelajaran terpadu tipe immersed pada pokok bahasan Minyak Bumi ternyata mean score beda lebih baik tapi tidak signifikan.

\subsection{Saran}

Perlu adanya penelitian lebih lanjut Kalau menggunakan pembelajaran terpadu tipe immersed pada mata pelajaran lain, perhatikan penyusunan TPB.

\section{DAFTAR PUSTAKA}

Anam, Choirul. 2002. Pengembangan Kurikulum Kompetensi dan evaluasi. Makalah disajikan dalam seminar FMIPA UNESA, tanggal 21 April 2003

Arends, R.I. 1997. Classroom Instructional and Management. New York: Mc. Graw-Hill Book Companies, Inc.

Arikunto, Suharsimi. 1998. Prosedur Penelitian Suatu Pendekatan Praktek. Jakarta: Rineka Cipta. 
Arikunto, Suharsimi. 2003. Dasar-dasar Evaluasi Pendidikan. Jakarta: Bumi Aksara.

Atwater, M., Baptiste, P.H, Daniel, L., Hackett, J., Moyer, R., Takemoto, C.\& Mathew, N. W., 1995. Teacher's Planning Guide, New York: Macmillan/McGraw-Hill.

Blazely, Lloyd D.et.all.1997. Science Study. Jakarta: The Japan Grand Foundation.

Borich, G. D. 1994. Observation Skill For Effective Teaching, New York: Macmillan Publishing Company.

Druxes H., Born G., Siemsen F. 1983. Compedium Didactic Physic. Munchen: Ehrenwirth Verlag GmBH \& Co. KG

Fogarty, Robin. 1991. How To Integrate The Curricula. Printed in United States of America.

Hadisubroto, T. 1998. Pembelajaran Terpadu: Materi Pokok PGSD. Jakarta: Universitas Terbuka.

Ibrahim, Muslimin, Fida Rahmadiarti, Muhammad Nur, Ismono. 2000. Pembelajaran Kooperatif. PSMS, Program Pasca Sarjana. Surabaya: University Press.

Kemp, N.E. 1994. The Instruction Design Process. New York: Harper \& Row College Publishing Inc. Penerjemah Asril Marjohan, Bandung: ITB.

Kurikulum SMU. 1994. Garis- garis Besar Program Pengajaran. Jakarta: Depdikbud.

Mulyasa. 2002. Kurikulum Berbasis Kompetensi. Bandung: PT Remaja Rosdakarya
Nur, Muhammad. 2002. Asesmen Tradisional, Asesmen Kinerja dan Rubrik. Makalah disajikan pada Program Contextual Learning Materials Development Proyek Peningkatan Mutu SLTP Jakarta Direktorat sekolah Lanjutan Tingkat Pertama Direktorat Jenderal Pendidikan Dasar dan Menengah Departemen Pendidikan Nasional In Collaboration With University of Washington College of Education, State university of Surabaya, State University of Malang and LAPI ITB, pada Januari 2002.

Nur, Muhammad. 1998. Teori- Teori Perkembangan. Surabaya: IKIP Surabaya. Pedoman Pengembangan Instrumen dan Penilaian Ranah Psikomotor. 2004. Jakarta: Departemen Pendidikan Nasional.

Slavin, R.E. 2000. Educational Psychology: Theory and Practice. Sxth Edition. Boston: Allyn \& Bacon Sudjana, 1996. Metoda Statistika. Bandung: Tarsito. 
Lampiran Analisis Respon siswa Terhadap Pembelajaran Terpadu Tipe Immersed

Tabel 4.8 Analisis Respon siswa Terhadap Pembelajaran Terpadu Tipe Immersed Uji Coba 1

\begin{tabular}{|c|c|c|c|c|c|}
\hline \multirow[b]{2}{*}{ No } & \multirow[b]{2}{*}{ Pertanyaan } & \multicolumn{4}{|c|}{ Respon Siswa (\%) } \\
\hline & & Senang & $\begin{array}{c}\text { Tidak } \\
\text { senang }\end{array}$ & Baru & $\begin{array}{l}\text { Tidak } \\
\text { baru }\end{array}$ \\
\hline \multirow[t]{5}{*}{1} & $\begin{array}{l}\text { Bagaimanakah pendapat anda terhadap komponen berikut ini } \\
\text { a. Materi }\end{array}$ & 80 & 20 & 80 & 20 \\
\hline & b. Bahan bacaan siswa & 90 & 10 & 80 & 20 \\
\hline & c. LKS & 90 & 10 & 90 & 10 \\
\hline & d. Kegiatan praktikum & 90 & 10 & 80 & 20 \\
\hline & e. Cara guru mengajar & 80 & 20 & 90 & 10 \\
\hline \multicolumn{2}{|r|}{ Rata - rata } & 86 & 14 & 84 & 16 \\
\hline 2 & $\begin{array}{l}\text { Apakah anda berminat mengikuti kegiatan belajar mengajar berikutnya } \\
\text { seperti yang telah anda lakukan saat ini ? }\end{array}$ & \multicolumn{2}{|c|}{$\mathrm{Ya}=90$} & \multicolumn{2}{|c|}{ Tidak $=10$} \\
\hline 3 & $\begin{array}{l}\text { Apakah kalian tertarik dan memahami } \\
\text { a. Bahasa yang digunakan } \\
\text { b. Penampilan bahan ajar } \\
\text { c. Ilustrasi / gambar - gambar pada buku }\end{array}$ & \multicolumn{2}{|c|}{$\begin{array}{l}80 \\
80 \\
90\end{array}$} & \multicolumn{2}{|c|}{$\begin{array}{l}20 \\
20 \\
10\end{array}$} \\
\hline
\end{tabular}

Tabel 4.9 Analisis Respon siswa Terhadap Pembelajaran Terpadu Tipe Immersed Uji Coba 2 Kelas Eksperimen 1

\begin{tabular}{|c|c|c|c|c|c|}
\hline \multirow[b]{2}{*}{ No } & \multirow[b]{2}{*}{ Pertanyaan } & \multicolumn{4}{|c|}{ Respon Siswa (\%) } \\
\hline & & Senang & $\begin{array}{c}\text { Tidak } \\
\text { senang }\end{array}$ & Baru & $\begin{array}{l}\text { Tidak } \\
\text { baru }\end{array}$ \\
\hline \multirow[t]{5}{*}{1} & $\begin{array}{l}\text { Bagaimanakah pendapat anda terhadap komponen berikut ini } \\
\text { a. Materi }\end{array}$ & 75 & 25 & 80 & 20 \\
\hline & b. Bahan bacaan siswa & 95 & 5 & 75 & 25 \\
\hline & c. LKS & 95 & 5 & 95 & 5 \\
\hline & d. Kegiatan praktikum & 95 & 5 & 75 & 25 \\
\hline & e. Cara guru mengajar & 75 & 25 & 95 & 5 \\
\hline \multicolumn{2}{|r|}{ Rata - rata } & 87 & 13 & 84 & 16 \\
\hline 2 & $\begin{array}{l}\text { Apakah anda berminat mengikuti kegiatan belajar mengajar berikutnya } \\
\text { seperti yang telah anda lakukan saat ini ? }\end{array}$ & \multicolumn{2}{|c|}{$\mathrm{Ya}=95$} & \multicolumn{2}{|c|}{ Tidak $=5$} \\
\hline 3 & $\begin{array}{l}\text { Apakah kalian tertarik dan memahami } \\
\text { a. Bahasa yang digunakan } \\
\text { b. Penampilan bahan ajar } \\
\text { c. Ilustrasi / gambar - gambar pada buku }\end{array}$ & \multicolumn{2}{|c|}{$\begin{array}{l}75 \\
80 \\
95\end{array}$} & \multicolumn{2}{|c|}{$\begin{array}{c}25 \\
20 \\
5\end{array}$} \\
\hline
\end{tabular}

Tabel 4.10 Analisis Respon siswa Terhadap Pembelajaran Terpadu Tipe Immersed Uji Coba 2 Kelas Eksperimen 2

\begin{tabular}{|c|c|c|c|c|c|}
\hline \multirow[b]{2}{*}{ No } & \multirow[b]{2}{*}{ Pertanyaan } & \multicolumn{4}{|c|}{ Respon Siswa (\%) } \\
\hline & & Senang & $\begin{array}{c}\text { Tidak } \\
\text { senang }\end{array}$ & Baru & $\begin{array}{c}\text { Tidak } \\
\text { baru }\end{array}$ \\
\hline 1 & $\begin{array}{l}\text { Bagaimanakah pendapat anda terhadap komponen berikut ini } \\
\text { a. Materi } \\
\text { b. Bahan bacaan siswa } \\
\text { c. LKS } \\
\text { d. Kegiatan praktikum } \\
\text { e. Cara guru mengajar }\end{array}$ & $\begin{array}{l}80 \\
85 \\
95 \\
90 \\
80\end{array}$ & $\begin{array}{c}20 \\
15 \\
5 \\
10 \\
20 \\
\end{array}$ & $\begin{array}{l}80 \\
80 \\
95 \\
80 \\
85 \\
\end{array}$ & $\begin{array}{c}20 \\
20 \\
5 \\
20 \\
15 \\
\end{array}$ \\
\hline & Rata - rata & 86 & 14 & 84 & 16 \\
\hline 2 & $\begin{array}{l}\text { Apakah anda berminat mengikuti kegiatan belajar mengajar berikutnya } \\
\text { seperti yang telah anda lakukan saat ini ? }\end{array}$ & \multicolumn{2}{|c|}{$\mathrm{Ya}=85$} & \multicolumn{2}{|c|}{ Tidak $=15$} \\
\hline 3 & $\begin{array}{l}\text { Apakah kalian tertarik dan memahami } \\
\text { a. Bahasa yang digunakan } \\
\text { b. Penampilan bahan ajar } \\
\text { c. Ilustrasi / gambar - gambar pada buku }\end{array}$ & \multicolumn{2}{|c|}{$\begin{array}{l}80 \\
80 \\
85\end{array}$} & \multicolumn{2}{|c|}{$\begin{array}{l}20 \\
20 \\
15\end{array}$} \\
\hline
\end{tabular}

